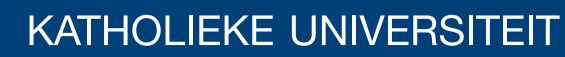 \\ LEUVEN
}

Faculty of Economics and Applied Economics

Predicting business/ICT alignment with AntMiner+

B. Cumps, D. Martens, M. De Backer, R. Haesen, S. Viaene,

G. Dedene, B. Baesens, M. Snoeck

DEPARTMENT OF DECISION SCIENCES AND INFORMATION MANAGEMENT (KB)) 


\title{
Predicting Business/ICT Alignment with AntMiner+
}

\author{
Bjorn Cumps a," ${ }^{\text {a }}$ David Martens ${ }^{\text {a }}$, Manu De Backer a , Raf Haesen ${ }^{\text {e,a }}$, \\ Stijn Viaene ${ }^{\text {a,b }}$, Guido Dedene $e^{\mathrm{a}, \mathrm{b}, \mathrm{c}}$, Bart Baesens ${ }^{\mathrm{d}, \mathrm{a}}$, Monique Snoeck ${ }^{\mathrm{a}}$ \\ ${ }^{a}$ Department of Decision Sciences and Information Management, \\ Katholieke Universiteit Leuven, Belgium \\ ${ }^{b}$ Department of Operations and Technology Management, \\ Vlerick Leuven Gent Management School, Belgium \\ ${ }^{c}$ Department of Economics and Business, \\ Free University of Amsterdam, The Netherlands \\ ${ }^{d}$ School of Management, \\ University of Southampton, United Kingdom \\ ${ }^{e}$ VLEKHO Business School Brussels, Belgium
}

\begin{abstract}
In this paper we report on the results of a European survey on business/ICT alignment practices. The goal of this study is to come up with some practical guidelines for managers on how to strive for better alignment of ICT investments with business requirements. Based on Luftman's alignment framework we examine 18 ICT management practices belonging to 6 different competency clusters. We use AntMiner+, a rule induction technique, to create an alignment rule set. The results indicate that B/ICT alignment is a multidimensional goal which can only be obtained through focused investments covering different alignment aspects. The obtained rule set is an interesting mix of both formal engineering and social interaction processes and structures. We discuss the implication of the alignment rules for practitioners.
\end{abstract}

Keywords: Business/ICT alignment, Data mining, Artificial ant systems, Practical guidelines 


\section{Introduction}

Alignment between business and ICT in organisations is still high on the management agenda of many a CIO. Most often, making sure that investments in ICT are in harmony with the organisation's business objectives proves to be more challenging than initially expected, especially in today's fast-changing, dynamic environment. A lot has been written on B/ICT alignment, yet there are few studies that come up with actionable results that can be used by practitioners [2]. Prior research focussed on conceptualising and justifying B/ICT alignment, resulting in numerous definitions, conceptual models, frameworks and links with business performance. This stream of literature focuses on what alignment is and why it is important. Although many papers include a section on practical implications of the study, few studies actually focus on the processes and structures that lead to alignment. Many leading authors in this field of study (Avisson [2], Chan [15], Sabherwal [62], Cragg [19], Hussain [33], Maes [45]) therefore urge future studies to focus on the practice of alignment. This study tries to answer the call for insight on how to achieve alignment. We make use of the alignment processes and structures suggested by the existing body of literature and use survey data to quantitatively test which set of processes and structures leads to highly aligned organisations.

The following section gives a literature overview in which we describe the focus of previous studies and give an outline of the theoretical lens we use for this study: resource-based view. Next we describe the setup of our research with a focus on how we operationalised the various concepts. This is followed by a section on the research methodology and analysis techniques. Finally, we discuss our results and translate our obtained rule set to practical management advice.

\section{Theoretical Development}

The paper first reviews the most important developments in alignment literature in order to place our contribution within the existing body of literature. This archival analysis results from an indepth literature study of almost 50 influential articles which all focus specifically on B/ICT alignment. We selected more than 10 journals that appear in published journal rankings [35], which frequently publish B/ICT alignment research articles. Appendix $\mathrm{C}$ gives an overview of the selection of articles and journals used for this discussion. We identified 3 major sub-themes in alignment research: defining, justifying and achieving B/ICT alignment. Next, we discuss each of these alignment sub-themes and relate our study to this discussion.

\subsection{Defining B/ICT Alignment}

A first theme in alignment research focuses on defining B/ICT alignment, often also referred to as fit [74], harmony [42], integration [75], linkage [31], bridge [17] or fusion [65]. As Chan [16] already points out, we can roughly distinguish two prevailing conceptualisations of the alignment problem. The first one, based on the work of Reich and Benbasat [58], focuses on planning and objectives integration whereas the second conceptualisation, based on Henderson and Venkatraman [31], take a more holistic view on alignment.

Reich and Benbasat [58] view alignment as the degree to which the ICT mission, objectives and plans support and are supported by the business mission, objectives and plans. Kearns and Lederer [37] follow this vision by arguing that by aligning the ICT plan and business plan, 
information resources support business objectives and take advantage of opportunities for strategic use of ICT. This conceptualisation is nearly not as holistic as Henderson and Venkatraman's [31]. They define 4 domains that need attention: business strategy, ICT strategy, business (infra)structure and ICT (infra)structure. Each of these domains has its constituent components: scope, competencies, governance, infrastructure, processes and skills. Maes [45] further refines this framework by splitting it up into a business, information/communication and technology column, and a strategy, structure and operations row. It is clear that this stream of research identifies more alignment components thus increasing both the complexity and the richness of the concept of alignment.

Other researchers added to the conceptualisation by pointing out the need for attention to both formal and social alignment elements [59, 16, 43]. In the research literature, there have been two perspectives on how organisations function. The first concentrates on examining the strategies, structures and planning methodologies in organisations. This stream of literature perceives organisations as formal, corporate entities, devoid of personalities, that can be engineered and built. The second investigates the actors in organisations, examining their values, communications with each other and the understanding of each others' domains. They perceive organisations as social systems of interrelated elements where a change in one element influences the others. It is clear that these two perspectives are at opposite ends of a range of intermediate options where formal and social elements cooperate to make organisations function properly, but few authors have focused on this interaction.

Reich and Benbasat $[58,59]$ make a distinction between short- and long-term B/ICT alignment. In their study they analyse the influence of the social and informal dimension of alignment. Intellectual and formal structures and planning processes between business and ICT were found to influence short-term alignment. Only informal aspects such as shared domain knowledge between business and ICT managers influence long-term alignment. They conclude that informal aspects of alignment are more lasting than formal alignment aspects.

Chan [16] confirms the importance of informal structures for B/ICT alignment. Her study emphasises the need for attention for informal elements such as trust, communication, culture, social bonds and virtual linkages. The presence of an informal structure permits the organisation to react quickly to internal and external shocks and to continue to excel while more formal strategies and structures need time to catch up and get updated. Chan [16] follows Reich and Benbasat [59] in their argument that informal organisational elements may be the most enduring aspect of alignment. She concludes that investments in formal alignment processes and structures are investments in a more transient form of alignment.

It is clear that the role of human actors in alignment is often not sufficiently acknowledged. This lack of attention for the social dimension too often results in the interpretation of alignment as merely engineering formal alignment structures and processes, meanwhile totally ignoring mechanisms such as organisational learning, trust building, communication, and other social interactions that play an important role in B/ICT alignment $[17,45]$.

Furthermore, there is still a lively discussion in literature on whether alignment should be studied as a process or an outcome $[58,2]$. Most studies conceptualise alignment as an outcome, a state or a result of a process rather than a process $[59,5,6,15,37]$. Others argue that alignment should be viewed as a continuous process, underlining the fact that alignment is not a one time activity but a constant balancing act between a lead or lag strategy $[45,16,17,43,32]$. In this paper we will argue that organisations need $a$ set of processes and structures to create an alignment capability. 


\subsection{Justifying B/ICT Alignment}

A second theme in alignment literature focuses on justifying $\mathrm{B} / \mathrm{ICT}$ alignment, i.e. showing the importance of organisations actively aligning business and ICT. Most studies choose either one of the previous conceptualisations, measure the degree of alignment and link this with business performance.

In general, we can say that B/ICT alignment is used by many authors to explain how ICT investments can generate business value. In light of the productivity paradox in information technology as discussed by Brynjolfsson [10], many researchers started looking for that intermediary concept that could explain why ICT investments did not always generate the expected results. One of the answers from the literature is that these investments have to be aligned with the business to be successful. If not aligned and managed properly, realising business value from ICT investments is like playing the lottery. Some will get lucky, most will not and the overall result will certainly not be positive. In this perspective, B/ICT alignment is important because it is an important catalyst for business value generation from ICT investments.

Most studies agree that B/ICT alignment has an impact on business performance. Teo and King [68] empirically validate the positive influence of integrated business and ICT planning on business performance. The same positive relationship was found by Sabherwal and Chan [62], Chan et al. [15], Cragg et al. [19] and Bergeron et al. [5]. Next to this direct effect on business performance, several studies look at the more indirect positive effects of B/ICT alignment. Kearns and Lederer [37, 38, 39] focus on how alignment can help create a sustainable competitive advantage for the organisation. Furthermore, they also describe how integrated business and ICT planning can help knowledge creation with both business and ICT executives regarding each other's domain. Both Chan [16] and Reich and Benbasat [59] emphasise the importance of benefits such as partnership and mutual domain understanding. Luftmann [43], Weill \& Broadbent [75] and Byrd et al. [13] argue that better alignment will lead to better and more focussed ICT investments and a more properly balanced ICT portfolio. Palmer and Markus [51] are of the few authors that did not find any significant impact from alignment on business performance using survey data.

Literature has shown that some caution may be in order. There may be risks involved with B/ICT alignment, definitely when not properly understood. Jarvenpaa and Ives [34] argue that if alignment is what they call "too tight", it reduces the organisation's strategic flexibility. Miller [48] supports this view stating that a so-called "overemphasis on alignment" could restrict the organisation's outlook, inhibiting the recognition of alternative perspectives and reducing the ability to recognise and respond to the need for change. Both Maes [45] and Ciborra [17] add to the discussion that alignment in practice is not always as flexible as their adherents presume. Management may not always be in full control. For example, it is notoriously hard to tune existing (often referred to as "legacy") ICT infrastructure and architecture with emerging business strategies. This typically takes time, a whole lot of scarce resources, as well as a significant amount of good-will from human actors in organisations to support the change. This is why Tushman and O'Reilly [72] argue that alignment facilitates short-term success, which can lead to inertia, which in turn can lead to failure when the market conditions change suddenly. Tallon and Kraemer [67] refer to this phenomenon as the alignment paradox: In the short term organisations reap the benefits of alignment, yet over a period of time, alignment becomes so rigid that organisations suffer a decline in ICT flexibility and agility, limiting their ability to respond easily to changing market conditions. 
In time of constant change, organisational agility and flexibility become increasingly important. Therefore, organisations cannot afford to risk loosing these desirable characteristics when focussing on alignment. However, they do not need to make this choice between either alignment or flexibility and agility. The problem of most studies which, rightfully, question the desirability of alignment is that they focussed on a much too narrow view on alignment. Both Pyburn [57] and Reich and Benbasat [59] demonstrated that the formal aspects of alignment are mainly mechanisms that have effect in the short run. Chan [16] adds to this, based on the work of the previous authors, the argument that informal organisational structures ensure flexibility and agility and are responsible for long-term alignment. Again, the combination of formal and social seem necessary for enduring B/ICT alignment.

\subsection{Achieving B/ICT Alignment}

As stated before, the existing body of literature provides little guidance on how to achieve alignment between business and ICT. Chan et al. [15] admit that the processes involved in achieving alignment were not studied. Sabherwal and Chan [62] argue that the process by which alignment is accomplished needs to be better understood. Cragg [19] states that we still know little on how alignment can actually be achieved and Hussain [33] diagnoses an important need in literature for processes associated with alignment. Yet, Ciborra [17] is able to formulate it most eloquently: Management, through knowledge and understanding of alignment, can classify their strategies in terms of boxes and linear relationships, but back in the real world, they have difficulty to formulate processes to apply the alignment maps in practice. Chen [14] follows this argument and calls for research that helps practitioners on how to gauge and manage alignment.

However, as pointed out by Avison [2], some authors do provide practical application of B/ICT alignment. Luftman [43], Yetton [76], Hsaio and Ormerod [30], Burn [11] and Papp [52] provide examples of enablers and inhibitors, yet fail to test the theories and methods in a practical manner in real life situations and organisations. This is where this paper is able to make a contribution. The previous paragraphs have demonstrated that there often is a lack of definitional rigor and uniformity in alignment conceptualisation. Furthermore, there is a strong need for research that studies how organisations do and should align. Both shortcomings can be clearly seen from the literature overview in appendix C. Empirical studies on the practice of alignment framed within a strong theoretical framework are needed to fill this gap in literature.

\subsection{Resource-based View}

In this paper we approach the alignment problem from a resource-based view perspective as it focuses on internal, organisation-specific factors to create a sustainable competitive advantage. As such, we contribute to the increasing body of literature that uses this theoretical lens to study $\mathrm{B} / \mathrm{ICT}$ alignment problems $[38,55,1,20]$. Resource-based view (RBV) argues that an organisation's bundle of resources, which include tangible and intangible assets, knowledge and skills, are the primary predictors of superior financial performance. The logic is that a sustainable competitive advantage can be created when there is resource heterogeneity (resources are different) across organisations and resource immobility (competitors find it hard to imitate or substitute these resources). Therefore, this view argues that an organisation should create unique, inimitable competencies as a means to create a sustainable marketplace advantage $[29,3,1,55]$. The core idea of RBV is that organisations cannot expect to "purchase" sustained competitive advantage in the open market. Rather, such advantage must be found in rare, imperfectly mobile, and non-substitutable resources already controlled by the organisation [29, 3]. With regards to

competitive advantage, RBV focuses much more on the internal organisation and less on the 
interaction with the competitors or the organisation's marketplace position as do other theories of the firm e.g. Porter's competitive forces, game theory and transaction cost economics.

Before we can enter into a discussion on the resource-based view of the firm we need to clearly define the terms and concepts underpinning this stream of literature. We use the framework of Peppard and Ward [55], which consists of three levels: the resource level, the organising level and the enterprise level. The resource level consists of the organisation's business and technical skills, knowledge and experience, complemented with the behaviour and attitudes present in the organisation. The organising level looks at how resources are transformed into competencies using the combination of processes, structures and roles. These competencies can then be transformed into a capability, which manifests itself at the enterprise level, and can be recognised in the performance of the organisation.

We opted to work with Peppard and Ward's framework because it clearly shows the dynamics of how resources can be transformed into an enterprise level capability. In previous literature there is often a lack of precision in the usage of terms and concepts surrounding RBV leading to contradictory definitions. Peppard and Ward try to introduce uniformity and make a clear distinction between resources, competencies and capabilities which enhances comprehensibility. They put forward the following definitions: Resources are stocks of available factors that are owned or controlled by the organisation i.e. information, systems, technology, skills and knowledge. Competencies refer to an organisation's capacity to deploy resources using processes, roles and structures to effect a desired end. Finally, a capability refers to the strategic application of competencies to accomplish organisational goals. Put differently, resources are what an organisation has under its control or at its disposal; competencies are the abilities of the organisation to develop, mobilise and use those resources; capability is what the business can achieve through focused investment and deployment of competencies [55].

B/ICT alignment can become such a unique capability as it satisfies both conditions of resource heterogeneity and resource immobility. Much of the knowledge and expertise on how to align business and ICT in an organisation is company-specific, tacit in nature and difficult to codify and replicate $[38,55]$. Company-specific capabilities develop in a cumulative and evolutionary matter and generally exhibit path-dependent characteristics [38, 29]. Furthermore, the ICT infrastructure and architecture, the available resources, the organisational structures, the company culture and many other aspects uniquely define an organisation. All of these are arguments in favour of the hypothesis that only those organisations that manage to align business and ICT using their unique mix of company-specific resources will be able to create an alignment capability that can be the basis of a sustainable competitive advantage. 


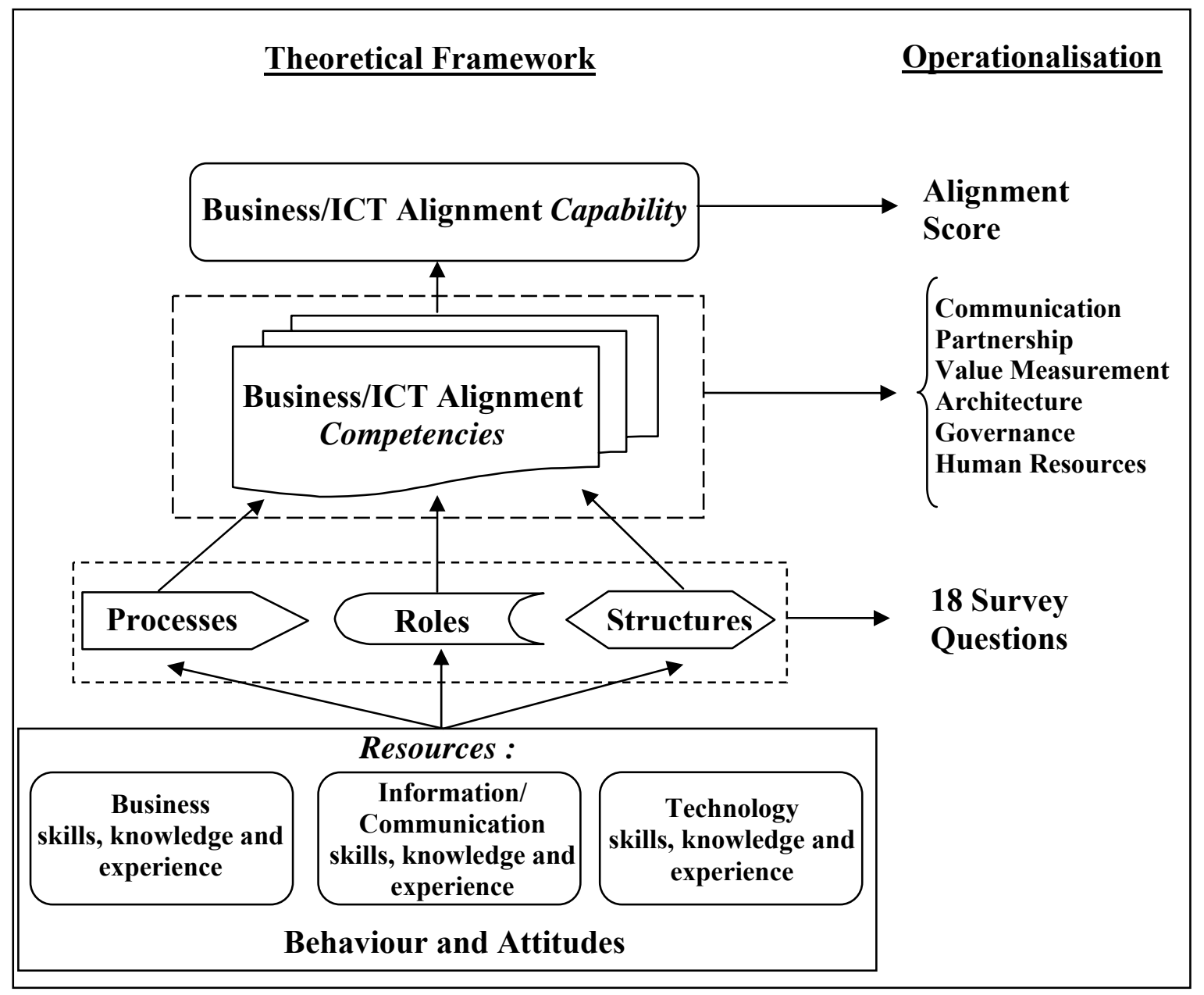

Figure 1: Theoretical framework and construct operationalisation

In figure 1 we made a few minor adaptations to Peppard and Ward's framework which make it more suitable for this discussion. Whereas they talk about Information Systems (IS) resources, competencies and capability, we talk about B/ICT alignment resources, competencies and capability. We feel confident doing this because B/ICT alignment literature fits quite well within this framework. As discussed before, previous literature focuses on defining what B/ICT alignment capability is and links this capability with business performance (enterprise level). At the organising level we also find studies that match with this framework. Without labelling it as such, Luftman [44] already defines a set of alignment competencies: Communication, partnership, value measurement, architecture, governance and human resources. Maes [45] makes a distinction between business, information/communication and technology resources. The behaviour, attitudes and roles found in figure 1 are a part of what Reich and Benbasat [59] and Chan [16] label as informal and social aspects of B/ICT alignment. Within the framework of figure 1, our focus is on the processes and structures used in organisations to create alignment competencies. 


\section{Research Setup}

The goal of our research is to come up with a set of alignment rules and guidelines that can help understand how alignment can be achieved in practice. We bundle a number of suggested useful alignment practices and test which ones contribute most to B/ICT alignment in organisations. First, we describe how we constructed our alignment capability measure. Next, we explain how we selected the 18 structures and processes in our data set.

\subsection{Alignment Capability}

Figure 1 shows how we operationalised our research constructs. To obtain a numerical assessment of the B/ICT alignment capability of an organisation we constructed an alignment score variable based on resource based view principles. This variable indicates the match between how the business perceives the role of ICT in the organisation and the ICT portfolio of systems the organisation adopts to support this. We use Treacy and Wiersema's [71] three value disciplines (operational excellence, product leadership and customer focus) as a basis for this variable. These value disciplines indicate in which strategic capability organisations invest their specific resources. Compared to traditional financial goals such as revenue growth, profit and business value maximisation, value disciplines are better indicators for the strategic direction of the organisation. According to Treacy \& Wiersema, organisations should focus on one of these value disciplines and try to excel in it, without neglecting the other two disciplines. However, next to these three value disciplines, we felt the need to include two other increasingly important disciplines. Based on the findings of Weill and Broadbent [75], we included enterprise integration and the creation of management information. Next to the traditional value disciplines, organisations spend a lot of time and money on both integration to create an enterprise-wide infrastructure and creation of information for management purposes. The Delphi panel confirmed the importance of these two disciplines. Appendix B shows the operationalisation of the alignment capability variable. We used the matching approach [74] to calculate the alignment score. Alignment capability varies significantly across organisations. The average alignment capability score is 13.2 out of 20 . Around $23 \%$ of organisations score 16 or above and $6 \%$ score 18 or over. However, still $23 \%$ of organisations score 10 or less.

\subsection{Alignment Competencies}

Based on our archival analysis, we selected a total of 26 structures and processes which organisations could use to create alignment competencies. Furthermore, we categorised each of these processes and structures according to Luftman's alignment categories (appendix A). Luftman's alignment model is used to illustrate that we opted for a diverse set of structures and processes able to cover each of the different categories. However, we are fully aware that these categories are not always mutually exclusive. Therefore, it is important to stress that Luftman's model was only used as a means to obtain a diverse set of structures and processes. Our initial set of almost 26 was reduced to 18 by the Delphi panel in order to increase relevance and reduce overlap as much as possible.

\section{Communication}

Several studies indicate that communication between business and ICT is key to achieve alignment. Lind and Zmud [41] empirically show the connection between communication frequency and convergence in understanding. Reich and Benbasat [59] found that shared domain knowledge, congruence between business and ICT vision and mutual understanding lead to better 
B/ICT alignment. Rockart, Earl and Ross state that communication helps to better integrate ICT in the business. Good communication, a shared vision and mutual understanding are reflected in the first three questions that could be regarded as the communication alignment competence.

\section{Partnership}

Teo and King [68] empirically validate the importance of business and ICT planning integration and find a significant positive relationship with organisational performance. Kearns and Lederer $[37,38]$ show that participation of the CIO in business planning has a positive effect on building a competitive advantage. In a follow-up study they also demonstrate the positive influence of information intensity between business and ICT on alignment performance. Reich and Benbasat [39] argue that connected planning has a positive influence on short-term alignment. Luftman [42, 43] argues that the business should be more involved in ICT projects. Connected and integrated planning, strategising and involvement are reflected in questions 4 through 6 that could be regarded as the partnership alignment competence.

\section{Architecture}

Brown and Magill [9] point out the link between ICT organisation (centralised/decentralised) and alignment. Ross states that ICT architecture and ICT support of business processes is important for alignment. Benson [4] argues the importance of impact analysis of new ICT investments on existing ICT infrastructure and architecture. Centralisation consistency, business process support and architecture impact analysis are reflected in questions 7 through 9 that could be regarded as the architecture alignment competence.

\section{Value Measurement}

The importance of value measurement and management for B/ICT alignment is often cited in literature. Henderson and Venkatraman [31] suggest that value management has a positive effect on B/ICT alignment as it makes visible that ICT investments generate business value. Tallon et al. $[66,67]$ found a positive relationship between ICT investment evaluation and B/ICT alignment. Benson [4] argues for both ICT investment prioritisation and benchmarking as alignment mechanisms. Business value demonstration, prioritisation and benchmarking are reflected in questions 10 through 12 that could be regarded as the value measurement alignment competence.

\section{Governance}

Henderson and Venkatraman [31] suggest that ICT governance is a key element in obtaining $\mathrm{B} / \mathrm{ICT}$ alignment. They point out the importance of budget controls and decision rights for ICT investments. Weill [75] argues that ICT governance leads to better alignment as it encourages desirable behaviour in the use of ICT through the allocation of decision rights and accountability. Benson [4] points out the importance of performance management and budget allocation in ICT governance. Budget allocation and transparency in decision rights and accountability are reflected in questions 13 through 15 that could be regarded as the governance alignment competence.

\section{Human Resources}

Luftman [44] points out the importance of the ability to attract and retain staff both knowledgeable in business and ICT. Both Rockart and Ross agree that ICT staff which possess both business and ICT skills are more valuable to an organisation than those with only technical skills. Blending business and ICT staff will help align business and ICT. ICT acceptance, stakeholder management and joint development are reflected in questions 16 through 18 that could be regarded as the human resources alignment competence. 


\section{Research Methodology}

The main goal of this research is to infer B/ICT alignment rules that can help academics understand how organisations can build an alignment capability and to help practitioners align business and ICT in their organisations. We opted for data mining, and more specifically for AntMiner + , as this technique is able to infer simple, understandable alignment rules which can easily be implemented. As we have a sufficiently large data set and have no predefined model in mind, data mining is the most suitable analysis technique.

\subsection{Data Collection}

We gathered the data using a restricted, web-based survey carried out in seven European countries (Belgium, France, Germany, United Kingdom, The Netherlands, Spain and Italy). Lists of organisations from different industries and different sizes were compiled and all organisations received an invitation and access code. The themes and questions included in the questionnaire were all subjected to a pre-test. The Delphi panel consisted of 4 academics with expertise in ICT management and survey design, 2 ICT management consultants and 4 ICT managers. This resulted in a more condensed set of processes and structures and some minor modifications in wording. The pre-testing contributed to a survey that is both academically sound and has practical relevance. For most of the questions, organisations had to evaluate themselves on a five-point Likert scale ranging from $1=$ strongly disagree to $5=$ strongly agree.

Range

Frequency

Percent

(a) Participation by country

$\begin{array}{llr}\text { United Kingdom } & 142 & 22 \\ \text { Belgium } & 140 & 22 \\ \text { France } & 95 & 15 \\ \text { Spain } & 97 & 15 \\ \text { The Netherlands } & 71 & 11 \\ \text { Italy } & 57 & 9 \\ \text { Germany } & 39 & 6\end{array}$

Total

(b) Total number of employees

$\begin{array}{lll}50-99 & 90 & 14 \\ 100-499 & 192 & 30 \\ 500-999 & 64 & 10 \\ 1000-2999 & 77 & 12 \\ >3000 & 218 & 34\end{array}$

Total

(c) Participation by industry*

CIPS 269

$269-42$

TICE 167

PUBLIC 
FINANCE

PHARMA

Total

(d) Participation by turnover

$<€ 10$ million

$€ 10 \mathrm{~m}-€ 49 \mathrm{~m}$

$€ 50 \mathrm{~m}-€ 99 \mathrm{~m}$

$€ 100 \mathrm{~m}-€ 499 \mathrm{~m}$

$€ 500 \mathrm{~m}-€ 999 \mathrm{~m}$

$>€ 1$ billion

Don't know

Total

(e) Participation by position

$\mathrm{CIO}$

Head of ICT department192

ICT managers

Business managers

CEO

$\mathrm{COO}$

Other
39

32

641

115

147

71

96

44

154

14

641
100

6

5

18

23

11

15

7

24

2

100

Total

141

96

38

26

7

141
22

30

15

6

4

1

22

\section{Total}

641

100

* CIPS $=$ Consumer and industrial products and services

TICE $=$ Technology, information, communication and entertainment

\section{Table 1: Profile of the responding organisations}

From the 790 responses received, we removed responses with too many missing values from the dataset, leaving us with 641 valid responses to the survey. Table 1 gives a breakdown of the sample by country, size, industry, turnover and respondents. We have a nice spread of countries, company sizes and industries in our sample. 22\% of respondents are CIO's, 30\% are the head of the ICT department and 15\% are ICT managers. This makes that the majority of respondents $(67 \%)$ have an ICT related function. Around $10 \%$ of respondents are CEO's or business managers. The remaining $22 \%$ have other busines functions in the organisation.

\subsection{Data Analysis}

We made use of a data mining technique to build a classification model to distinguish the highly aligned from the poorly aligned organisations. The technique used, AntMiner+, is based on artificial ant systems and builds rule sets with proven predictive capabilities [26]. We will first shortly discuss the artificial ant systems, followed by a brief overview of the AntMiner+ technique. 
Artificial ant systems are inspired on the behaviour of real ant colonies and are part of a relatively new concept in artificial intelligence, called swarm intelligence [25]. Swarm Intelligence is the property of a system whereby the collective behaviours of (unsophisticated) agents interacting locally with their environment cause coherent functional global patterns to emerge. A biological ant is a simple insect with limited capabilities but an ant colony is able to behave in complex manners and come to intelligent solutions for problems such as the transportation of heavy items and finding the shortest path between the food source and the nest. This complex behaviour emerges from self-organisation and indirect communication between the ants. The indirect way of communication, through the environment rather than directly between the individuals, is also known as stigmergy [70]. More specifically, ants communicate through a chemical substance called pheromone that each ant drops on its path. When an ant finds a pheromone trail it is likely to follow this path and reinforce the pheromone. The pheromone trail intensity is increased and the path will become more likely to be followed by other ants. In turn, when no ants follow the same path the pheromone trail intensity decreases, this process is called evaporation.

These principles are illustrated in figure 2. Two ants start from their nest (left) and are looking for the shortest path to a food source (right). Initially no pheromone is present on either trail, so there is a 50-50 chance of choosing either of the two possible paths. Suppose one ant chooses the lower trail and the other one the upper trail. The ant that has chosen the lower (shorter) trail will have returned faster to the nest, resulting in twice as many pheromones on the lower trail as on the upper one. As a result, the probability that the next ant will choose the lower, shorter trail will be twice as high, resulting in more pheromone and thus more ants that will choose this trail, until eventually (almost) all ants will follow the shorter path.
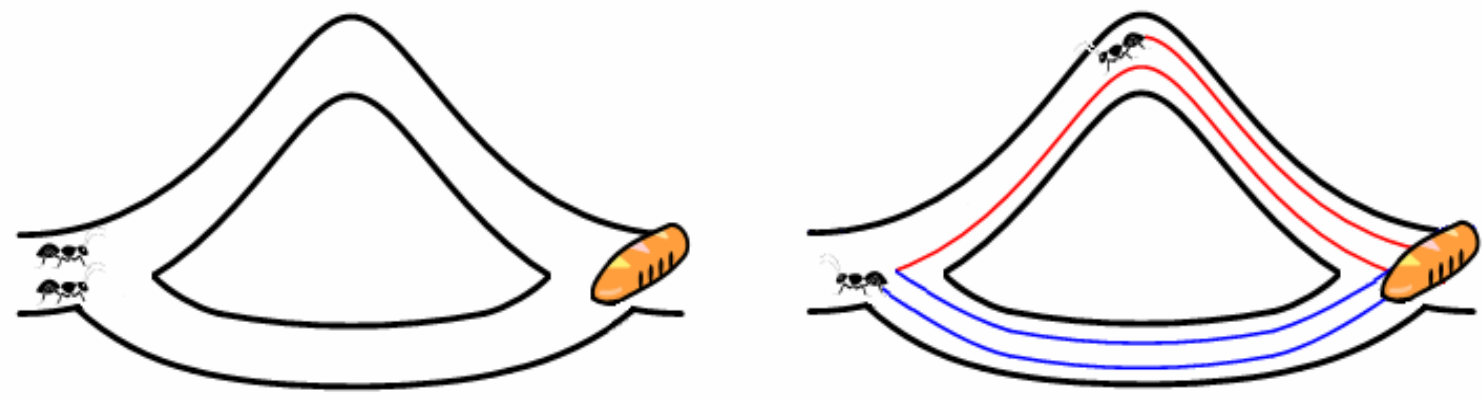

Figure 2: Path selection with ants using pheromones

These principles have been applied to create multi-agent systems, mimicking their biological counterparts. This approach has shown to be a viable method for attacking hard combinatorial optimization problems, like the Travelling Salesman Problem [24], routing packages through the Internet [23] and Traffic Light Control [50].

Recently, a stigmergy based approach to data mining has been proposed, resulting in the AntMiner+ classification technique. The aim is to extract simple if-then-else rules from data. First of all, an environment for the ants to walk through is defined, as a directed, acyclic construction graph which allows a clear representation of the problem domain. The construction graph is defined as follows: each 'column' or vertex group corresponds to a variable and every 'row' corresponds to a value. Each ant going from vertex $v_{i, j}$ to vertex $v_{i+1, k}$ adds the term $<V_{i+1}=$ Value $_{\mathrm{k}}>$ to its rule. To allow for rules where not all the variables are involved, an extra dummy 
vertex is added whose value is undetermined, meaning it can take any of the values available. Although only categorical variables can be used in our implementation, we make a distinction between nominal and ordinal variables. Each nominal variable has one vertex group, but for the ordinal however, we build two vertex groups to allow for intervals to be chosen by the ants. The first vertex group corresponds to the lower bound of the interval and should thus be interpreted as $\left\langle\mathrm{V}_{\mathrm{i}+1} \geq \mathrm{Value}_{\mathrm{k}}\right\rangle$, the second vertex group determines the upper bound, giving $\left\langle\mathrm{V}_{\mathrm{i}+2} \leq \mathrm{Value}_{\mathrm{k}}\right\rangle$. This allows having less, shorter and actually better rules. Figure 3 provides a reduced construction graph for our B/ICT alignment data. Although we show only two variables (Q1 and Q2), we actually have 18. An ant that has chosen the path denoted in boldface, implicitly as constructed the rule (with $\mathrm{SA}=$ strongly agree, $\mathrm{A}=$ agree, $\mathrm{N}=$ neutral, $\mathrm{D}=$ disagree, $\mathrm{SD}=$ strongly disagree):

if $\mathrm{Q} 1 \geq \mathrm{SA}$ and $\mathrm{Q} 1 \leq \mathrm{N}$ and $\mathrm{Q} 2 \geq \mathrm{SA}$ and $\mathrm{Q} 2 \leq \mathrm{A}$

then highly aligned

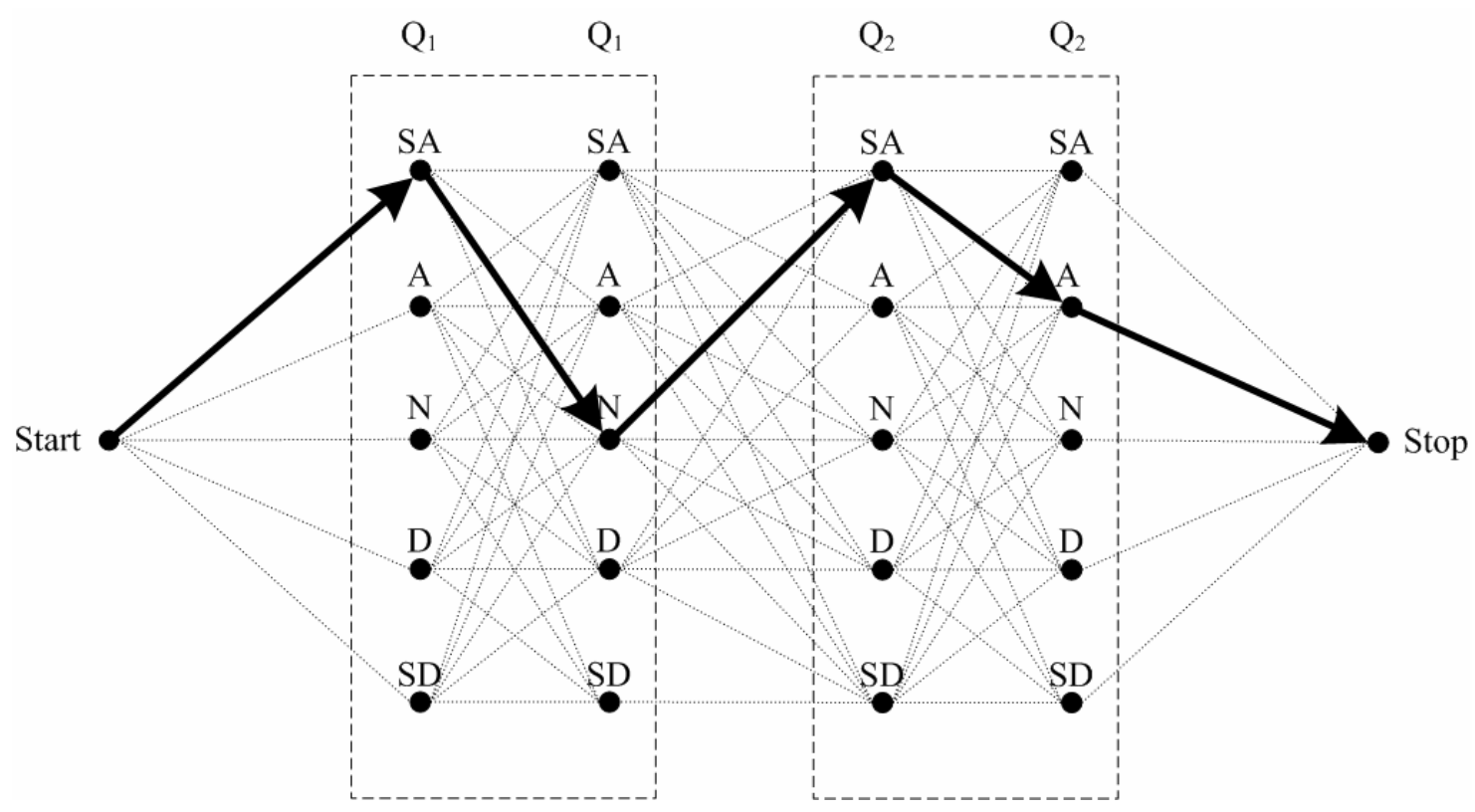

Figure 3: Reduced construction graph for B/ICT alignment data

The basic workings of this technique are shown below and goes as follows. Within one iteration all ants begin in the start vertex and walk to the end vertex, hereby choosing their path in the stochastic manner described before, depending on the heuristic and pheromone values. Once the ants have arrived, the path of the best ant is updated, i.e. the pheromone increased, while the other paths have their pheromone lowered by evaporation. After a number of iterations, the pheromone level of one path will be very high, while the pheromone values of the other paths will have a minimal value. Consequently, (almost) all ants will choose this path and describe the same rule: convergence occurs. The described rule is extracted, all data instances that are described by that rule are removed from the data set (to avoid the extraction of identical rules) and a new iteration follows. Finally, the algorithm ends when a sufficient percentage of the data is described by the extracted rule set. 


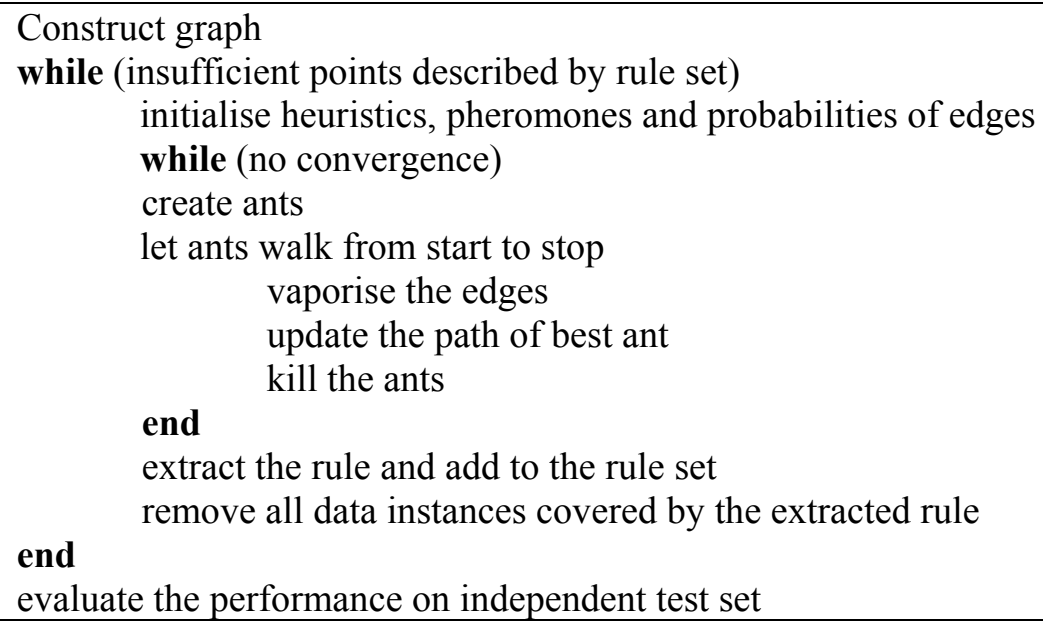

The performance of a data mining technique is typically measured by its accuracy on an independent test set, simply by calculating the percentage of the data instances that are correctly classified by the model. It is not our goal to compare different data mining techniques in this paper. The AntMiner+ algorithm has been benchmarked with state-of-the-art data mining techniques on a variety of data sets $[26,46]$. These experiments reveal outstanding performances with the supplementary benefit of generating comprehensible rule sets.

\section{Results}

The AntMiner+ algorithm infers 2 rules from our data. These rules provide accurate predictions for $69.29 \%$ of the companies included in our data set. As our data set is established by means of a survey, contradictory data will inevitable be present. As a consequence of these idiosyncrasies, also known as noise, higher accuracies will be very hard to achieve by any classification model. Having 2 rules that provide accurate predictions for almost $70 \%$ of the data is a fairly good result.

Rules from AntMiner+ :

\section{If $Q 4 \leq 3$ And $Q 13 \leq 2$ And $Q 7 \leq 3$ And $Q 11 \leq 3$ And $Q 6 \leq 3$ Then class $=0$ \\ 2. If $Q 13 \leq 3$ And $Q 7 \leq 2$ And $Q 3 \leq 2$ And $Q 11 \leq 2$ Then class $=0$ \\ 3. Else class $=1$}

With $1=$ strongly agree, $2=$ agree, $3=$ neither agree nor disagree, $4=$ disagree, $5=$ strongly disagree, class $0=$ highly aligned, class $1=$ poorly aligned.

The most important advantage of using AntMiner+ for this analysis is that it generates comprehensible rules. These rules can be represented in a fairly simple if-then-else statement. 


\section{If-Then-Else rules inferred by AntMiner+}

If Business and ICT planning processes are tightly integrated

And Performance management impacts budget allocation

And Alignment processes at a centralised and decentralised level are in line

And ICT investments are prioritised against business strategy

And There is a clear business ownership for ICT projects

Then Organisation is highly aligned

Else if Performance management impacts budget allocation

And Alignment processes at a centralised and decentralised level are in line

And The business has a good understanding of the impact of ICT

And ICT investments are prioritised against business strategy

Then Organisation is highly aligned

Else Organisation is poorly aligned

\section{Discussion}

The rules inferred from the data make one thing very clear. B/ICT alignment is a complex and multi-dimensional phenomenon. A combination of 4 or 5 different processes or structures is needed for organisations to score high on the alignment capability variable. Furthermore, there is not one alignment competence that dominates the rules. Both rules are a combination of what Luftman calls partnership, communications, governance, architecture and value measurement competencies. This is an important result for practitioners. Investing in only one of these alignment competencies will not lead to better B/ICT alignment. Our results clearly indicate that the combination of these different competencies makes for high alignment.

Our first rule combines 5 alignment processes and structures. First of all, business and ICT planning and management processes should be tightly connected and integrated. We should not be surprised that this process emerges as an important one. Joint or integrated planning and management is perhaps one of the most heavily researched topics in alignment literature [37, 59, 64, 68, 69]. Our results confirm the importance of this alignment competence. Connected and integrated planning not only makes explicit what is important for both business and ICT (leading to better shared domain knowledge), but also helps to see how ICT can support future business strategies and how future ICT developments can enable business decisions. Secondly, ICT performance management should impact budget allocation. Organisations need to monitor and measure the performance of their ICT investments and use this as a guide to steer ICT budget allocation decisions. A possible explanation for the importance is that it stimulates to better manage and govern ICT investments leading to more focussed investments that are on time, budget and scope. Thirdly, strategic B/ICT alignment processes at a centralised level have to be in line with strategic B/ICT alignment processes at a decentralised level. This means, for example, that it is important for organisations to have uniformity in the way they implement alignment processes across headquarters and subsidiaries. Organisations have to make sure that alignment processes defined at a centralised level are understood and implemented at the decentralised level in order to better align ICT with business requirements. Fourthly, ICT investment spending should 
be prioritised against business strategy. This process makes sure that organisations only spend money on those ICT investments that best relate to business requirements. Prioritisation can help practitioners to rank possible ICT investments according to their contribution to business strategy. This results in an ICT investment portfolio that better supports business requirements. Finally, there should be a clear business ownership for ICT projects. Business and ICT should be partners on every ICT project. Business ownership not only includes the business in ICT projects, it also makes them responsible for the outcome and fit with business requirements.

If we have a closer look at the two rules inferred by AntMiner+ we notice that both rules select the following:

- $\quad$ ICT investments are prioritised against business strategy

- Performance management impacts budget allocation

- Alignment processes at a centralised and decentralised level are in line

As these practices are selected in both rules as differentiating conditions between highly and poorly aligned organisations, we can conclude that the combination of these three core alignment practices is the minimal necessary set to obtain a high alignment score. However, we stress that they always have to occur in combination with 2 (for rule 1) or 1 (for rule 2) other practices in order to retain their differentiating power.

The second rule adds only 1 other practice to the three core alignment practices i.e. the business has a good understanding of the impact of ICT. This shared domain understanding can lead to better and more informed decisions of the business as they understand the limitations and possibilities of ICT. Notice that this can be classified as an informal/social aspect of alignment (shared domain knowledge) as defined by Reich and Benbasat [59]. Managers who understand both their core business and the impact of ICT on their organisation, can use this knowledge to better leverage ICT innovations. Organisations should recognise that ICT knowledge and understanding is a core competence for business managers.

\section{Limitations}

Despite the contributions, there are inherent limitations of the study that warrant caution in interpreting and applying the research findings. First, our measure of alignment performance is based on a matching score methodology. The literature identifies different ways of measuring alignment effects: matching, moderation, mediation, covariation, profile deviation and gestalt approach are the most common. Different ways of measuring could lead to different results and different alignment rule sets. However, there is no clear indication in literature on how to precisely measure alignment. Next, the results of this study are based on a set of 18 alignment processes and structures. Although we used the literature to select the most relevant ones for $\mathrm{B} / \mathrm{ICT}$ alignment, we cannot claim that we were exhaustive. Adding new and different processes and structures to the set of 18 we used could change the obtained rule set. Finally, subjective data were employed in the study. Scores on the 18 processes and structures are perceptual and based on self-assessment. 


\section{Conclusion}

In summary, this study contributes to our understanding of B/ICT alignment in the following ways: First, we gave an extensive literature overview to come to a theoretical base in which we can frame our study. We use resource based view to define B/ICT alignment competencies and the processes and structures that lead to these competencies. On our extensive data set of over 640 European organisations, we use a novel data mining technique based on artificial ant systems to infer simple and understandable B/ICT alignment rules. The rules obtained from AntMiner+ are a useful guideline for practitioners. The advantage of this analysis technique is that we obtain a model from the data. The rule set also empirically validates the literature's call for a blending of formal and social alignment elements. The rule set is comprised of predominantly formal processes and structures. Yet, shared domain knowledge and mutual understanding, typically social elements, emerge as important alignment enablers in combination with the previous formal elements. Finally, this study contributes to the literature as it focuses on alignment processes and structures. There is a strong need for insight into the practice of alignment. The rule set obtained inferred from the data can give a good indication for practitioners on how to align business and ICT in their respective organisations. 


\section{Appendix A. Operationalisation of alignment competencies}

In your organisation ... (ranging from 1 = strongly disagree to 5 = strongly agree)

\section{Communication}

1. Business and ICT speak the same language

2. Business and ICT management have a shared vision of the role of ICT in enabling business strategies

3. Business management has a good understanding of the impact of ICT on the business

\section{Partnership}

4. Business and ICT planning and management processes are tightly connected and integrated

5. Innovations in ICT are taken into account when determining the business strategy

6. Your organisation fosters a clear business ownership for ICT projects

\section{$\underline{\text { Architecture }}$}

7. Strategic business/ICT alignment processes at a centralised level are in line with strategic business/ICT alignment processes at a decentralised level

8. Business processes are adequately supported by ICT

9. Your organisation systematically determines the impact of new ICT investments on existing business processes, systems and infrastructure

\section{$\underline{\text { Value Measurement }}$}

10. Your organisation is able to clearly demonstrate the value for its ICT investments

11. New ICT investment and enhancement spend is prioritised against business strategy

12. The performance of new ICT investment projects is regularly monitored and benchmarked against strategic objectives

\section{$\underline{\text { Governance }}$}

13. ICT performance management impacts budget allocation 
14. There is transparency in the levels of authority and responsibilities for making decisions with respect to ICT projects

15. There is transparency in the levels of accountability for outcomes for ICT projects

\section{$\underline{\text { Human Resource }}$}

16. Your organisation is able to minimise the resistance to change that comes with new ICT projects

17. Your organisation fosters a clear stakeholder management for ICT projects

18. In your organisation key-Users participate in the design and development of new ICT systems 


\section{Appendix B. Operationalisation of alignment capability}

Alignment score using matching approach:

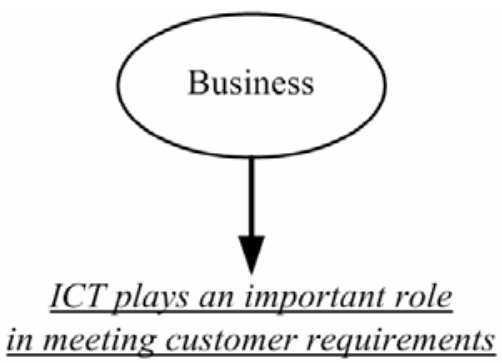

strongly disagree 12 2(3) $4 \begin{array}{lll}5 & \text { strongly agree }\end{array}$

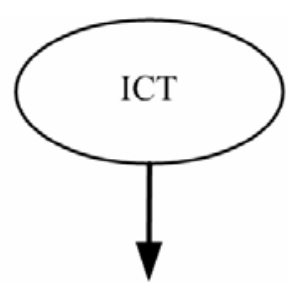

We have a high level of adoption of CRM systems

strongly disagree 1 2 2(3) 45 strongly agree

alignment score $=0($ misalignment $=4)$

alignment score $=\mathbf{4}($ misalignment $=0)$

\begin{tabular}{|l|l|}
\hline \multicolumn{1}{|c|}{ Business } & \multicolumn{1}{c|}{ ICT } \\
\hline $\begin{array}{l}\text { ICT plays an important role in meeting } \\
\text { customer requirements }\end{array}$ & We have a high adoption of CRM systems \\
\hline $\begin{array}{l}\text { ICT plays an important role in obtaining } \\
\text { better management information }\end{array}$ & $\begin{array}{l}\text { We have a high adoption of business } \\
\text { intelligence and knowledge management } \\
\text { systems }\end{array}$ \\
\hline $\begin{array}{l}\text { ICT plays an important role in cost } \\
\text { reduction and efficiency improvement }\end{array}$ & $\begin{array}{l}\text { We have a high adoption of transactional } \\
\text { and ERP systems }\end{array}$ \\
\hline $\begin{array}{l}\text { ICT plays an important role in enterprise } \\
\text { integration }\end{array}$ & $\begin{array}{l}\text { We have a high adoption of enterprise } \\
\text { application integration systems }\end{array}$ \\
\hline $\begin{array}{l}\text { ICT plays an important role in product } \\
\text { development }\end{array}$ & $\begin{array}{l}\text { We have a high adoption of product } \\
\text { lifecycle management systems }\end{array}$ \\
\hline
\end{tabular}




\section{Appendix C. Archival analysis}

\begin{tabular}{|c|c|c|}
\hline Journal Title & \# of papers & Authors \\
\hline California Management Review & 2 & $\begin{array}{l}\text { Hirschheim \& Sabherwal } 2001 \\
\text { Luftman \& Brier } 1999 \\
\text { Tushman and O’Reilly } 1996\end{array}$ \\
\hline Decision Sciences & 3 & $\begin{array}{l}\text { Das et al., } 1991 \\
\text { Kearns \& Lederer } 2003 \\
\text { Sabherwal and Kirs, } 1994\end{array}$ \\
\hline IBM Systems Journal & 4 & $\begin{array}{l}\text { Broadbent \& Weill } 1993 \\
\text { Henderson \& Venkatraman } 1993 \\
\text { Keen } 1993 \\
\text { Luftman et al. } 1993\end{array}$ \\
\hline Information \& Management & 7 & $\begin{array}{l}\text { Bergeron et al. } 2004 \\
\text { Burn \& Szeto } 2000 \\
\text { Byrd et al. } 2006 \\
\text { Kearns \& Lederer } 2004 \\
\text { Miller, 1993 } \\
\text { Peak et al. 2005 } \\
\text { Teo and King, } 1996\end{array}$ \\
\hline Information Systems Management & 5 & $\begin{array}{l}\text { Brown } 2003 \\
\text { Feurer et al. } 2000 \\
\text { Luftman } 2003 \\
\text { Moody } 2003 \\
\text { Peak \& Guynes } 2003 \\
\end{array}$ \\
\hline Information Systems Research & 5 & $\begin{array}{l}\text { Chan et al. } 1997 \\
\text { Palmer and Markus, } 2000 \\
\text { Peak and Guynes, } 2003 \\
\text { Sabherwal \& Chan } 2001 \\
\text { Segars and Grover } 1999\end{array}$ \\
\hline $\begin{array}{l}\text { Journal of Management Information } \\
\text { Systems }\end{array}$ & 3 & $\begin{array}{l}\text { Tallon and Kraemer } 2000 \\
\text { Teo and King, } 1997 \\
\text { Van Der Zee \& De Jong } 1999\end{array}$ \\
\hline Journal of Strategic Information Systems & 4 & $\begin{array}{l}\text { Avison et al. } 2004 \\
\text { Cragg et al. } 2002 \\
\text { Kearns \& Lederer } 2000 \\
\text { Peppard \& Ward } 2004\end{array}$ \\
\hline MIS Quarterly & 7 & $\begin{array}{l}\text { Brown and Magill } 1994 \\
\text { Clemons \& Row } 1991 \\
\text { King, } 1978 \\
\text { Pyburn } 1983 \\
\text { Reich \& Benbasat } 1996 \\
\text { Reich \& Benbasat } 2000 \\
\text { Sambamurthy \& Zmud, } 1999\end{array}$ \\
\hline MISQ Executive & 1 & Chan 2002 \\
\hline Organization Science & 4 & $\begin{array}{l}\text { Brown \& Magill, } 1998 \\
\text { Lind and Zmud. } 1991 \\
\text { Miller } 1992 \\
\text { Sabherwal et al. } 2001 \\
\end{array}$ \\
\hline Other Journals & 4 & $\begin{array}{l}\text { Ciborra, } 1997 \\
\text { Hussain et al. } 2001 \\
\text { Maes, 2000 } \\
\text { Tallon \& Kraemer, } 2003\end{array}$ \\
\hline
\end{tabular}




\begin{tabular}{|c|c|c|c|c|c|}
\hline Authors & Alignment Concept & Measures & Type of Study & Focus & Results \\
\hline $\begin{array}{l}\text { Pyburn } \\
(1983)\end{array}$ & $\begin{array}{l}\text { Link between MIS plan and corporate } \\
\text { strategy plan }\end{array}$ & Not measured & $\begin{array}{c}\text { Qualitative research } \\
\text { Exploratory case studies } \\
\text { Cross-sectional }\end{array}$ & $\begin{array}{c}\text { Formal and social enablers } \\
\text { described. No alignment process } \\
\text { defined. }\end{array}$ & $\begin{array}{l}\text { Importance of loose-tight } \\
\text { management and mix of formal and } \\
\text { social aspects }\end{array}$ \\
\hline $\begin{array}{l}\text { Henderson and } \\
\text { Venkatraman } \\
\text { (1993) }\end{array}$ & $\begin{array}{l}\text { Interaction and integration of business } \\
\text { strategy, business structure, ICT } \\
\text { strategy, ICT structure }\end{array}$ & Not measured & $\begin{array}{l}\text { Qualitative research } \\
\text { Theory building } \\
\text { Cross-sectional }\end{array}$ & $\begin{array}{c}\text { Distinction between strategic } \\
\text { alignment, operational alignment, } \\
\text { business alignment and ICT } \\
\text { alignment }\end{array}$ & $\begin{array}{c}\text { Different alignment perspectives exist } \\
\text { and require a different way of } \\
\text { managing }\end{array}$ \\
\hline $\begin{array}{l}\text { Luftman et al. } \\
\text { (1993) }\end{array}$ & $\begin{array}{c}\text { Interaction and integration of business } \\
\text { strategy, business structure, ICT } \\
\text { strategy, ICT structure }\end{array}$ & Not measured & $\begin{array}{l}\text { Qualitative research } \\
\text { Theory building } \\
\text { Cross-sectional }\end{array}$ & $\begin{array}{c}\text { Enablers and inhibitors of } \\
\text { alignment. High level alignment } \\
\text { process defined }\end{array}$ & $\begin{array}{l}\text { Pragmatic application of strategic } \\
\text { alignment framework into } \\
\text { management framework }\end{array}$ \\
\hline $\begin{array}{l}\text { Broadbent } \\
\text { and Weill } \\
(1993)\end{array}$ & $\begin{array}{l}\text { Interaction and integration of business } \\
\text { strategy, organisational structure, } \\
\text { technology strategy, ICT policies }\end{array}$ & Not measured & $\begin{array}{l}\text { Qualitative research } \\
\text { Interviews } \\
\text { Cross-sectional }\end{array}$ & $\begin{array}{l}\text { Formal methods } \\
\text { Enablers defined. No alignment } \\
\text { process defined. }\end{array}$ & $\begin{array}{l}\text { Enabling organisational practices } \\
\text { identified and questions generated }\end{array}$ \\
\hline $\begin{array}{l}\text { Keen } \\
(1993)\end{array}$ & $\begin{array}{l}\text { Link between deployment if ICT and } \\
\text { managing ICT strategy }\end{array}$ & Not measured & $\begin{array}{l}\text { Qualitative research } \\
\text { Theory building } \\
\text { Cross-sectional } \\
\end{array}$ & $\begin{array}{c}\text { Formal and social enablers } \\
\text { defined. No alignment process } \\
\text { defined. }\end{array}$ & $\begin{array}{c}\text { Assessment of divide between } \\
\text { deployment and management of ICT } \\
\text { using a fusion map }\end{array}$ \\
\hline $\begin{array}{l}\text { Brown } \\
\text { and Magill } \\
(1994)\end{array}$ & $\begin{array}{l}\text { Interaction between ICT organisation } \\
\text { and business environment }\end{array}$ & Not measured & $\begin{array}{l}\text { Qualitative research } \\
\text { Interviews } \\
\text { Cross-sectional }\end{array}$ & $\begin{array}{c}\text { Formal methods } \\
\text { Profiles identified. No alignment } \\
\text { process defined. }\end{array}$ & $\begin{array}{c}\text { Potential drivers or enablers are } \\
\text { identified that predict a firm's ICT } \\
\text { organisation (degree of centralisation) }\end{array}$ \\
\hline $\begin{array}{c}\text { Teo and } \\
\text { King } \\
(1996)\end{array}$ & $\begin{array}{l}\text { Integration of business plan (BP) and } \\
\text { information systems plan (ISP) }\end{array}$ & $\begin{array}{l}\text { Mediation } \\
\text { approach }\end{array}$ & $\begin{array}{l}\text { Quantitative research } \\
\text { Matched pair survey } \\
\text { Cross-sectional }\end{array}$ & $\begin{array}{l}\text { Relationship BP-ISP and } \\
\text { organisational impact. No } \\
\text { alignment process defined. }\end{array}$ & $\begin{array}{l}\text { Empirical validation of positive } \\
\text { relationship between BP-ISP } \\
\text { integration and firm performance }\end{array}$ \\
\hline $\begin{array}{c}\text { Reich and } \\
\text { Benbasat } \\
(1996) \\
\end{array}$ & $\begin{array}{l}\text { Support of ICT mission and plans by } \\
\text { business mission and plans and vice } \\
\text { versa }\end{array}$ & $\begin{array}{c}\text { Self-assessment on } \\
\text { newly developed } \\
\text { linkage scales }\end{array}$ & $\begin{array}{c}\text { Qualitative research } \\
\text { Interviews } \\
\text { Cross-sectional } \\
\end{array}$ & $\begin{array}{c}\text { Distinction intellectual/social and } \\
\text { short/long term alignment. No } \\
\text { alignment process defined. }\end{array}$ & $\begin{array}{l}\text { Importance social dimension of } \\
\text { alignment: mutual understanding and } \\
\text { shared vision }\end{array}$ \\
\hline $\begin{array}{l}\text { Chan et al. } \\
\text { (1997) }\end{array}$ & $\begin{array}{l}\text { Link between business strategic } \\
\text { orientation and ICT strategic } \\
\text { orientation }\end{array}$ & $\begin{array}{l}\text { Matching and } \\
\text { moderation used and } \\
\text { compared }\end{array}$ & $\begin{array}{l}\text { Quantitative research } \\
\text { Factor analysis } \\
\text { Cross-sectional }\end{array}$ & $\begin{array}{l}\text { Model testing and refining } \\
\text { measuring instrument. No } \\
\text { alignment process defined. }\end{array}$ & $\begin{array}{l}\text { Findings suggest that high strategic } \\
\text { alignment leads to better business } \\
\text { performance }\end{array}$ \\
\hline $\begin{array}{l}\text { Luftman } \\
\text { and Brier } \\
(1999)\end{array}$ & $\begin{array}{c}\text { Interaction between business strategy, } \\
\text { business structure, ICT strategy, ICT } \\
\text { structure }\end{array}$ & $\begin{array}{l}\text { Self-assessment and } \\
\text { scoring models used } \\
\text { and matched }\end{array}$ & $\begin{array}{c}\text { Qualitative and quantitative } \\
\text { research } \\
\text { Longitudinal }\end{array}$ & $\begin{array}{c}\text { Evolution of perceived alignment } \\
\text { enablers and inhibitors } \\
\text { High level process defined }\end{array}$ & $\begin{array}{l}\text { Similar enablers and inhibitors exist } \\
\text { and remain stable over time. Create } \\
\text { enablers through alignment process }\end{array}$ \\
\hline $\begin{array}{c}\text { Van der Zee } \\
\text { and De Jong } \\
(1999)\end{array}$ & $\begin{array}{c}\text { Integrated business and ICT } \\
\text { management }\end{array}$ & Not measured & $\begin{array}{l}\text { Qualitative research } \\
\text { Theory building } \\
\text { Cross-sectional }\end{array}$ & $\begin{array}{l}\text { Using the balanced scorecard to } \\
\text { integrate business and ICT. } \\
\text { High level process defined }\end{array}$ & $\begin{array}{l}\text { Alignment suffers from a time gap. } \\
\text { BSC can help business and ICT to be } \\
\text { aligned from start of projects }\end{array}$ \\
\hline $\begin{array}{l}\text { Maes } \\
(1999)\end{array}$ & $\begin{array}{c}\text { Interaction between business, } \\
\text { information/communication and } \\
\text { technology strategy, structure and } \\
\text { operations } \\
\end{array}$ & Not measured & $\begin{array}{l}\text { Qualitative research } \\
\text { Theory building } \\
\text { Cross-sectional }\end{array}$ & $\begin{array}{c}\text { Expand the Henderson and } \\
\text { Venkatraman model to a generic } \\
\text { framework. No alignment process } \\
\text { defined. } \\
\end{array}$ & $\begin{array}{c}\text { Information and communication } \\
\text { strategy, structure and operation play } \\
\text { a crucial alignment function between } \\
\text { business and ICT }\end{array}$ \\
\hline $\begin{array}{c}\text { Burn } \\
\text { and Szeto } \\
(2000)\end{array}$ & $\begin{array}{c}\text { Interaction between business strategy, } \\
\text { business structure, ICT strategy, ICT } \\
\text { structure }\end{array}$ & Not measured & $\begin{array}{c}\text { Qualitative and quantitative } \\
\text { research } \\
\text { Cross-sectional }\end{array}$ & $\begin{array}{c}\text { Business and ICT perspectives on } \\
\text { influential alignment factors. No } \\
\text { alignment process defined. }\end{array}$ & $\begin{array}{l}\text { No significant differences between } \\
\text { business and ICT managers on } \\
\text { important factors }\end{array}$ \\
\hline $\begin{array}{l}\text { Kearns and } \\
\text { Lederer } \\
(2000)\end{array}$ & $\begin{array}{l}\text { Integration of business plan with ICT } \\
\text { plan and reciprocal integration }\end{array}$ & $\begin{array}{l}\text { Self-assessment of the } \\
\text { degree of integration }\end{array}$ & $\begin{array}{l}\text { Quantitative research } \\
\text { Factor analysis (SEM) } \\
\text { Cross-sectional }\end{array}$ & $\begin{array}{l}\text { Integration of plans and perceived } \\
\text { potential of ICT for comp. adv. } \\
\text { No alignment process defined. }\end{array}$ & $\begin{array}{l}\text { ISP-BP alignment leads to expectation } \\
\text { that ICT leads to comp. adv. } \\
\text { BP-ISP similar but not for CIO's }\end{array}$ \\
\hline
\end{tabular}




\begin{tabular}{|c|c|c|c|c|c|}
\hline $\begin{array}{l}\text { Reich and } \\
\text { Benbasat } \\
(2000)\end{array}$ & $\begin{array}{c}\text { Support of business mission and plans } \\
\text { with ICT mission and plans and vice } \\
\text { versa }\end{array}$ & $\begin{array}{l}\text { Self-assessment on } \\
\text { "degree of mutual } \\
\text { understanding" scales }\end{array}$ & $\begin{array}{l}\text { Qualitative research } \\
\text { Interviews } \\
\text { Cross-sectional }\end{array}$ & $\begin{array}{l}\text { Influence of several factors on the } \\
\text { social dimension of alignment. No } \\
\text { alignment process defined. }\end{array}$ & $\begin{array}{c}\text { Communication, implementation } \\
\text { success, connected planning influence } \\
\text { short term alignment. Shared domain } \\
\text { knowledge long term alignment }\end{array}$ \\
\hline $\begin{array}{l}\text { Feurer } \\
\text { et al. } \\
(2000)\end{array}$ & $\begin{array}{c}\text { Interaction between business strategy, } \\
\text { business actions, ICT strategy and } \\
\text { actions }\end{array}$ & Not measured & $\begin{array}{l}\text { Qualitative research } \\
\text { Case study } \\
\text { Cross-sectional }\end{array}$ & $\begin{array}{c}\text { Shows an alignment framework } \\
\text { used in practice. } \\
\text { Detailed process defined }\end{array}$ & $\begin{array}{l}\text { Shows how business requirements are } \\
\text { translated into process requirements } \\
\text { and mapped onto applications }\end{array}$ \\
\hline $\begin{array}{l}\text { Sabherwal } \\
\text { and Chan } \\
(2001)\end{array}$ & $\begin{array}{c}\text { Interaction and integration of business } \\
\text { strategy, business structure, ICT } \\
\text { strategy, ICT structure }\end{array}$ & $\begin{array}{l}\text { Profile deviation } \\
\text { approach }\end{array}$ & $\begin{array}{l}\text { Quantitative research } \\
\text { Classification } \\
\text { Cross-sectional } \\
\end{array}$ & $\begin{array}{l}\text { Impact of alignment on perceived } \\
\text { business performance. No } \\
\text { alignment process defined. }\end{array}$ & $\begin{array}{l}\text { Alignment affects perceived business } \\
\text { performance only for some strategy } \\
\text { choices (prospectors, analyzers) }\end{array}$ \\
\hline $\begin{array}{l}\text { Sabherwal } \\
\text { et al. } \\
\text { (2001) }\end{array}$ & $\begin{array}{c}\text { Interaction between business and ICT } \\
\text { strategies }\end{array}$ & $\begin{array}{l}\text { Profile deviation } \\
\text { approach }\end{array}$ & $\begin{array}{l}\text { Qualitative research } \\
\text { Case study } \\
\text { Longitudinal }\end{array}$ & $\begin{array}{l}\text { Insight into alignment dynamics } \\
\text { by defining evolution patters. No } \\
\text { alignment process defined. }\end{array}$ & $\begin{array}{c}\text { Alignment dynamics can be described } \\
\text { by a punctuated equilibrium model: } \\
\text { evolutionary periods are punctuated } \\
\text { by revolutionary periods }\end{array}$ \\
\hline $\begin{array}{l}\text { Hirschheim } \\
\text { and Sabherwal } \\
(2001)\end{array}$ & $\begin{array}{l}\text { Support of business mission and plans } \\
\text { with ICT mission and plans and vice } \\
\text { versa }\end{array}$ & $\begin{array}{l}\text { Profile deviation } \\
\text { approach }\end{array}$ & $\begin{array}{l}\text { Qualitative research } \\
\text { Case study } \\
\text { Longitudinal }\end{array}$ & $\begin{array}{l}\text { Insight into alignment dynamics } \\
\text { by defining transition paths. No } \\
\text { alignment process defined. }\end{array}$ & $\begin{array}{l}\text { Three problematic trajectories } \\
\text { identified that lead to misalignment: } \\
\text { paradoxical decisions, excessive } \\
\text { transformation, uncertain turnarounds }\end{array}$ \\
\hline $\begin{array}{l}\text { Cragg } \\
\text { et al. } \\
(2002)\end{array}$ & $\begin{array}{l}\text { Interaction between business strategy } \\
\text { and ICT strategy }\end{array}$ & $\begin{array}{l}\text { Matching and } \\
\text { moderation models } \\
\text { used and compared }\end{array}$ & $\begin{array}{l}\text { Quantitative research } \\
\text { Factor analysis } \\
\text { Cross-sectional }\end{array}$ & $\begin{array}{l}\text { Apply existing alignment theory } \\
\text { on small organisations. No } \\
\text { alignment process defined. }\end{array}$ & $\begin{array}{l}\text { Moderation approach appeared more } \\
\text { effective in identifying alignment and } \\
\text { high alignment leads to better } \\
\text { organisational performance }\end{array}$ \\
\hline $\begin{array}{l}\text { Kearns and } \\
\text { Lederer } \\
(2003)\end{array}$ & $\begin{array}{l}\text { Integration of business plan with ICT } \\
\text { plan and reciprocal integration }\end{array}$ & $\begin{array}{c}\text { Self-assessment } \\
\text { combined with scoring } \\
\text { model }\end{array}$ & $\begin{array}{l}\text { Quantitative research } \\
\text { Factor analysis (SEM) } \\
\text { Cross-sectional }\end{array}$ & $\begin{array}{l}\text { Influence of knowledge sharing } \\
\text { on B/ICT alignment and link with } \\
\text { competitive advantage. No } \\
\text { alignment process defined. }\end{array}$ & $\begin{array}{l}\text { Information intensity leads to } \\
\text { integrative planning. Participation of } \\
\text { CIO in business planning has positive } \\
\text { effect on competitive advantage }\end{array}$ \\
\hline $\begin{array}{l}\text { Luftman } \\
(2003)\end{array}$ & $\begin{array}{c}\text { Interaction and integration of business } \\
\text { strategy, business structure, ICT } \\
\text { strategy, ICT structure }\end{array}$ & Scoring model & $\begin{array}{l}\text { Qualitative research } \\
\text { Theory building } \\
\text { Cross-sectional }\end{array}$ & $\begin{array}{l}\text { Develop a methodology to asses } \\
\text { an organisation's level of } \\
\text { alignment. No alignment process } \\
\text { defined. }\end{array}$ & $\begin{array}{l}\text { Alignment can be scored as the degree } \\
\text { of maturity of: communication, } \\
\text { partnership, value measurement, } \\
\text { governance, architecture and skills }\end{array}$ \\
\hline $\begin{array}{l}\text { Bergeron } \\
\text { et al. } \\
(2004)\end{array}$ & $\begin{array}{c}\text { Interaction and integration of business } \\
\text { strategy, business structure, ICT } \\
\text { strategy, ICT structure }\end{array}$ & $\begin{array}{l}\text { Covariation and } \\
\text { profile deviation } \\
\text { approach }\end{array}$ & $\begin{array}{l}\text { Quantitative research } \\
\text { Factor analysis (SEM) } \\
\text { Cross-sectional }\end{array}$ & $\begin{array}{l}\text { Analyse different alignment } \\
\text { patterns between } 4 \text { constructs. No } \\
\text { alignment process defined. }\end{array}$ & $\begin{array}{l}\text { Low-performance organisations } \\
\text { exhibit a conflictual alignment pattern } \\
\text { of the } 4 \text { alignment constructs }\end{array}$ \\
\hline $\begin{array}{l}\text { Kearns and } \\
\text { Lederer } \\
(2004)\end{array}$ & $\begin{array}{l}\text { Integration of business plan with ICT } \\
\text { plan and reciprocal integration }\end{array}$ & $\begin{array}{l}\text { Self-assessment of the } \\
\text { degree of integration }\end{array}$ & $\begin{array}{l}\text { Quantitative research } \\
\text { Factor analysis (SEM) } \\
\text { Cross-sectional } \\
\end{array}$ & $\begin{array}{l}\text { Influence of industry context on } \\
\text { impact of alignment on business } \\
\text { performance. }\end{array}$ & $\begin{array}{l}\text { Positive influence of environmental } \\
\text { uncertainty and information intensity } \\
\text { on alignment performance }\end{array}$ \\
\hline $\begin{array}{l}\text { Avison } \\
\text { et al. } \\
(2004)\end{array}$ & $\begin{array}{c}\text { Interaction between business, } \\
\text { information/communication and } \\
\text { technology strategy, structure and } \\
\text { operations }\end{array}$ & Not measured & $\begin{array}{l}\text { Qualitative research } \\
\text { Case study } \\
\text { Cross-sectional }\end{array}$ & $\begin{array}{c}\text { Test whether the strategic } \\
\text { alignment framework }(\mathrm{H} \& \mathrm{~V}) \text { has } \\
\text { practical relevance. } \\
\text { High level process defined }\end{array}$ & $\begin{array}{l}\text { Defines a high level management } \\
\text { process based on SAM to determine } \\
\text { and steer alignment perspectives }\end{array}$ \\
\hline $\begin{array}{l}\text { Peak } \\
\text { et al. } \\
(2005)\end{array}$ & $\begin{array}{l}\text { Interaction between business } \\
\text { corporate strategy, business unit } \\
\text { strategy, and ICT strategy }\end{array}$ & Not measured & $\begin{array}{l}\text { Qualitative research } \\
\text { Interviews } \\
\text { Cross-sectional } \\
\end{array}$ & $\begin{array}{l}\text { Describe a detailed technology } \\
\text { alignment planning process. }\end{array}$ & $\begin{array}{c}\text { Describe a detailed technology } \\
\text { alignment planning process using an } \\
\text { alignment roadmap }\end{array}$ \\
\hline $\begin{array}{l}\text { Byrd } \\
\text { et al. } \\
(2006)\end{array}$ & $\begin{array}{c}\text { Interaction between business and ICT } \\
\text { strategies }\end{array}$ & $\begin{array}{l}\text { Matching, moderation, } \\
\text { coordination and } \\
\text { integration }\end{array}$ & $\begin{array}{l}\text { Quantitative research } \\
\text { Moderated regression } \\
\text { Cross-sectional }\end{array}$ & $\begin{array}{l}\text { Examining } 4 \text { align. perspectives } \\
\text { and their link with ICT payoff. No } \\
\text { alignment process defined. }\end{array}$ & $\begin{array}{c}\text { Process alignment factors and } \\
\text { outcome alignment factors have a } \\
\text { leveraging effect on ICT investments }\end{array}$ \\
\hline
\end{tabular}




\section{References}

[1] Andreu, R., and Ciborra, C., "Organisational learning and core capabilities development: the role of it”, Journal of Strategic Information Systems, 5(2), 1996.

[2] Avison, D., Jones, J., Powell, P. and Wilson, D., "Using and Validating the Strategic Alignment Model,” Journal of Strategic Information Systems, Vol. 13, No. 3, 2004.

[3] Barney, J.B. "Firm resources and sustained competitive advantage", Journal of Management, 17(1), 1991.

[4] Benson, R.J., Bugnitz, T., and Walton, B., "From Business Strategy to IT Action: Right Decisions for a Better Bottom Line”, John Wiley \& Sons, 2004.

[5] Bergeron, F., Raymond, L. and Rivard, S., "Ideal Patterns of Strategic Alignment and Business Performance", Information and Management, Vol. 41, no 8, 2004 pp. 1003-1020.

[6] Broadbent, M. and Weill, P., "Improving Business and Information Strategy Alignment: Learning from the Banking Industry," IBM Systems Journal, Vol. 32, No. 1, 1993, pp. 162-179.

[7] Brown, C.V., "Performance Metrics for IT Human Resource Alignment," Information Systems Management, Vol. 20, No. 4, 2003.

[8] Brown, C. V., and Magill, S. L. "Reconceptualizing the Context-Design Issue for the Information Systems Function,” Organization Science, 9(2), 1998, pp. 176-194.

[9] Brown, C.V., and Magill, S.L. "Alignment of the is function with the enterprise: towards a model of antecedents", MIS Quarterly, 18(4), 1994.

[10] Brynjolfson, E., "The productivity paradox of information technology", Communications of the ACM, 36(12), 1993.

[11] Burn, J., "Information system Strategies and the Management of Organisational Change", Journal of Information Technology, 8, 1997.

[12] Burns, J.M., and Szeto, C., "A Comparison of the Views of Business and IT Management on Success Factors for Strategic Alignment," Information and Management, Vol. 37, 2000, pp. 197216.

[13] Byrd, T.A., Lewis, B.R., and Bryan, R.W., "The leveraging influence of strategic alignment on IT investment: an empirical examination", Information \& Management, 43(3), 2006.

[14] Chen, H.M., Kazman, R., and Garg, G., "BITAM: an engineering principled method for managing misalignments between business and IT architectures", Science of Computer Programming, 57(1), 2005. 
[15] Chan, Y.E., Huff, S.L., Barclay, D.W. and Copeland, D.G., "Business Strategy Orientation, Information Systems Orientation and Strategic Alignment," Information Systems Research, Vol. 8, No. 2, 1997, pp. 125-150.

[16] Chan, Y.E., "Why Haven't we Mastered Alignment? The Importance of the Informal Organization Structure.," MIS Quarterly Executive, Vol. 1, No. 2, 2002.

[17] Ciborra, C.U., "De Profundis? Deconstructing the Concept of Strategic Alignment," Scandinavian Journal of Information Systems, 9(1), 1997, pp. 67-82.

[18] Clemons E.K., and Row, M.C., "Sustaining it advantage: The role of structural differences". MIS Quarterly, 15(3), 1991.

[19] Cragg, P., King, M. and Hussin, H., "IT Alignment and Firm Performance in Small Manufacturing Firms," Journal of Strategic Information Systems, Vol. 11, No. 2, 2002.

[20] Cumps, B., Viaene, S., Dedene, G., and Vandenbulcke, J., "An empirical study on business/ict alignment in european organisations". In Electronic proceedings of the $39^{\text {th }}$ Hawaiien International Conference on System Sciences (HICSS 39), Kauai, Hawaii, January 2006.

[21] Das, S.R., Zahra, M.E., and Warketin, M.E., "Integrating the content and concept of strategic planning with competitive strategy”, Decision Sciences, Vol. 22, 1991.

[22] Dedene, G., Viaene, S., Cumps, B., and De Backer, M., "An abc-based approach for operational business/ict alignment". In Proceedings of the 11th European Conference on Information Technology Evaluation (ECITE), Amsterdam, The Netherlands, November 2004.

[23] Di Caro, G. and Dorigo, M., "Antnet: Distributed stigmergetic control for communications networks", Journal of Artificial Intelligence Research, 9:317-365, 1998.

[24] Dorigo, M., Maniezzo, V. and Colorni, A., "The ant system: Optimization by a colony of cooperating agents", IEEE Transactions on Systems, Man, and Cybernetics Part B: Cybernetics, 26(1):29-41, 1996.

[25] Dorigo, M. and St"utzle, T., “Ant Colony Optimization”, Bradford Book, 2004.

[26] De Backer, M., Haesen, R., Martens, D., Baesens, B., “A Stigmergy Based Approach to Data Mining, Lecture Notes in Computer Science, Springer, p.975-978, 2005.

[27] Earl, M.J., "Management Strategies for Information Technology," Business Information Technology Series, Prentice Hall Europe, 1989.

[28] Feurer, R., Chaharbaghi, K., Weber, M. and Wargin, J., “Aligning Strategies, Processes, and IT: A Case Study,” Information Systems Management, Vol. 17, No. 1, 2000.

[29] Grant, R.M., "The resource-based theory of competitive advantage: implications for strategy formulation”. California Management Review, 33(3), 1991.

[30] Hsaio, R., Ormerod, R., "A New Perspective on the Dynamics of IT-Enabled Strategic Change", Information Systems Journal, 8 (1), 1998. 
[31] Henderson, J.C. and Venkatraman, N., "Strategic Alignment: Leveraging Information Technology for Transforming Organizations," IBM Systems Journal, Vol. 32, No. 1, 1993, pp. 416.

[32] Hirschheim R. and Sabherwal R., "Detours in the Path toward Strategic Information Systems Alignment: Paradoxical Decisions, Excessive Transformations, and Uncertain Turnarounds," California Management Review, 44(1), Fall 2001, pp. 87-108.

[33] Hussain, H., King, M., Cragg, P., "IT Alignment in Small Firms”, European Journal of Information Systems, 11, 2001.

[34] Jarvenpaa, S.L., and Ives, B., "The global network organization of the future: Information management opportunities and challenges". Journal of Management Information Systems, 10(4), 1994.

[35] Katerattanakul, P., Han, B., and Hong, S., "Objective Quality Ranking of Computing Journals," Communications of the ACM, Vol 46, No. 10, 2003.

[36] Keen, P.G.W., "Information Technology and the Management Difference: A Fusion Map," IBM Systems Journal, Vol. 32, No. 1, 1993.

[37] Kearns, G.S. and Lederer, A.L., "The Effect of Strategic Alignment on the use of IS-Based Resources for Competitive Advantage," Journal of Strategic Information Systems, Vol. 9, No. 4, 2000 .

[38] Kearns, G.S. and Lederer, A.L., “A Resource-Based View of Strategic IT Alignment: How Knowledge Sharing Creates Competitive Advantage," Decision Sciences, Vol. 34, No. 1, 2003.

[39] Kearns, G.S. and Lederer, A.L., "The impact of industry contextual factors on IT focus and the use of IT for competitive advantage," Information \& Management, Vol. 41, 2004, pp. 899919.

[40] King, W.R., "Strategic Planning for Management Information Systems," MIS Quarterly, Vol. 2, No. 1, 1978, pp. 27-37.

[41] Lind, M.R., and Zmud, R.W., "The influence of a convergence in understanding between technology providers and users on information technology innovativeness", Organization Science, 2(2), 1991

[42] Luftman, J.N., Lewis, P.R. and Oldach, S.H., "Transforming the Enterprise: The Alignment of Business and Information Technology Strategies," IBM Systems Journal, Vol. 32, No. 1, 1993.

[43] Luftman, J.N., Brier, T., "Achieving and Sustaining Business-IT Alignment," California Management Review, Vol. 42, No. 1, 1999.

[44] Luftman, J.N., “Assessing IT/Business Alignment," Information Systems Management, Vol. 20, No. 4, 2003.

[45] Maes, R., Rijsenbrij, D., Truijens, O. and Goedvolk, H., "Redefining Business-IT Alignment through a Unified Framework," PrimaVera Working Paper Series, 2000-19, 2000. 
[46] Martens, D., De Backer, M., Haesen, R., Baesens, B. and Holvoet, T., "Ants Constructing Rule-Based Classifiers", Swarm Intelligence and Data Mining, Springer, chapter 2, p.21-44, 2006.

[47] Miller, D. ”Environmental fit versus internal fit". Organization Science, 3(2), 1992.

[48] Miller, J., "Measuring and aligning information systems with the organization". Information and Management, 25(4), 1993.

[49] Moody, K.V., "New Meaning to IT Alignment" Information Systems Management, Vol. 20, No. 4, 2003.

[50] Oliveira, D., Ferreira, P. and Bazzan, A. L. C., "Reducing traffic jams with a swarm based approach for selection of signal plans", In Proceedings of Fourth International Workshop on Ant Colony Optimization and Swarm Intelligence - ANTS 2004, volume 3172 of LNCS, pages 416, 417, Berlin, Germany, 2004.

[51] Palmer J.W., and Markus, M.L., "The performance impacts of quick response and strategic alignment in specialty retailing”. Information Systems Research, 11(3), 2000.

[52] Papp, R., "Strategic Information Technology: Opportunities for Competitive Advantage", IDEA Publishing Group, 2001.

[53] Peak, D. and Guynes, S.C., "Improving Information Quality Through IT Alignment and Planning: A Case Study," Information Systems Management, Vol. 20, No. 4, 2003.

[54] Peak, D., Guynes, S.C. and Kroon, V., "Information Technology Alignment Planning - A case study," Information \& Management, Vol. 42, 2005, pp. 619-633.

[55] Peppard, J. and Ward, J., "Beyond Strategic Information Systems: Towards an IS Capability,” Journal of Strategic Information Systems, Vol. 13, No. 2, 2004.

[56] Powell, T.C., and Dent-Micallef, A., "Information technology as competitive advantage: the role of human, business and technology resources", Strategic Management Journal, 18(5), 1997.

[57] Pyburn, P.J., "Linking the MIS Plan with Corporate Strategy: An Exploratory Study," MIS Quarterly, Vol. 7, No. 2, 1983, pp. 1-14.

[58] Reich, B.H. and Benbasat, I., "Measuring the Linkage between Business and Information Technology Objectives," MIS Quarterly, Vol. 20, No. 1, 1996, pp. 55-81.

[59] Reich, B.H. and Benbasat, I., "Factors that Influence the Social Dimension of Alignment between Business and Information Technology Objectives," MIS Quarterly, Vol. 24, No. 1, 2000, pp. 81 .

[60] Sambamurthy, V. and Zmud, R.W., "Factors Influencing Information Technology Management Architectures in Organizations. A Theory of Multiple Contingencies," MIS Quarterly, Vol. 23, No. 2, 1999.

[61] Sabherwal, R., Hirschheim R. and Goles T., "The Dynamics of Alignment: Insights from a Punctuated Equilibrium Model," Organization Science, 12(2), March-April 2001, 179-197. 
[62] Sabherwal, R.and Chan, Y. E., "Alignment Between Business and IS Strategies: A Study of Prospectors, Analyzers, and Defenders," Information Systems Research, 12(1), March 2001, pp. 11-33.

[63] Sabherwal, R., and Kirs, P., "The alignment between organizational critical success factors and information technology capability in academic institutions", Decision Sciences, 25(2), 1994.

[64] Segars, A.H., and Grover, V., "Profiles of strategic information systems planning", Information Systems Research, 10(3), 1999.

[65] Smaczny, T., "IS an Alignment between Business and IT the Appropriate Paradigm to Manage IT in Today’s Organisation?", Management Decision, 39 (10), 2001.

[66] Tallon, P.P., Kraemer, K.L., and Gurbaxani, V., "Executives' Perceptions of the Business Value of Information Technology: A Process-Oriented Approach," Journal of MIS, Vol. 16, No. 4, 2000, pp. 145-173.

[67] Tallon, P.P. and Kraemer, K.L. "How Flexibility Shapes Strategic Alignment and IT Business Value: Uncovering an Alignment Paradox," CRITO Working Paper UC-Urvine, 2003.

[68] Teo, T.S.H, and King, W.R., "Assessing the impact of integrating business planning and is planning”, Information and Management, 30(6),1996.

[69] Teo, T.S.H and King, W.R., "Integration between business planning and information systems planning: an evolutionary-contingency perspective", Journal of Management Information Systems, 14(1), 1997.

[70] Theraulaz, G. and Bonbeau, E., “A brief history of stigmergy”, Artif. Life, 5(2):97-116, 1999.

[71] Treacy, M., and Wiersema, F., "The discipline of market leaders: Choose your customers, narrow your focus, dominate your market", Perseus book group, 1997.

[72] Tushman, M.L., and O'Reilly, C.M., "Ambidextrous organizations: Managing evolutionary and revolutionary change", California Management Review, 38(4), 1996.

[73] Van Der Zee, J.T.M. and De Jong, B., "Alignment is not Enough: Integrating Business and Information Technology Management with the Business Balanced Scorecard," Journal of Management Information Systems, Vol. 16, No. 2, 1999.

[74] Venkatraman, N., "The concept of fit in strategy research". Academy of Management Review, 14(3), 1989.

[75] Weill, P. and Broadbent M., Leveraging the New Infrastructure: "How Market Leaders Capitalize on Information Technology," Harvard Business School Press, Boston, MA, 1998.

[76] Yetton, P., "False prophecies, Successful Practice, and Future Directions in IT Management", In: Sauer, C., Yetton, P. et al. (Eds.), Steps to the Future. Jossey-Bass, San Francisco, 1997. 